\title{
DEMOGRAFICZNE UWARUNKOWANIA ZAPOTRZEBOWANIA NA USLUGI ASYSTENCKIE I OPIEKUŃCZE WŚRÓD OSÓB STARSZYCH W POLSCE
}

\begin{abstract}
Streszczenie
Zapotrzebowanie na ustugi asystenckie i opiekuńcze dla osób starszych determinowane jest między innymi uwarunkowaniami demograficznymi. Polska podobnie jak inne kraje rozwinięte doświadcza postępującego procesu starzenia się populacji, którego dynamika w najbliższych dziesięcioleciach znacznie wzrośnie. Starzenie się społeczeństw implikuje wiele wyzwań, w tym także konieczność zapewnienia opieki niesamodzielnym osobom starszym. Celem artykutu jest analiza wybranych demograficznych uwarunkowań procesu starzenia się społeczeństwa polskiego. Przedmiot dokonanej analizy stanowi weryfikacja hipotezy o zmniejszajacych się możliwościach sprawowania opieki nad osobami starszymi przez członków najbliższej rodziny w świetle postępującego procesu starzenia się spoleczeństwa polskiego w perspektywie czasowej do 2080 roku. W artykule wykorzystano informacje zamieszczone w bazie danych Eurostatu (https://ec.europa.eu/eurostat/data/ database) oraz dane z badania pt: Stan zdrowia ludności Polski w 2014 r., którego

* Marta Luty-Michalak - dr n. hum. w zakresie socjologii, adiunkt w Katedrze Metodologii Badań i Analiz Socjologicznych, Instytut Socjologii, Wydział Nauk Historycznych i Społecznych, Uniwersytet Kardynała Stefana Wyszyńskiego w Warszawie, ekspert ds. polityki senioralnej w projekcie pt. „Profesjonalizacja usług asystenckich i opiekuńczych dla osób niesamodzielnych - nowe standardy kształcenia i opieki”, współfinansowanym przez Unię Europejską (nr projektu POWR. 02.08.00-00-0018/17-00). Zainteresowania badawcze: procesy demograficzne i społeczne we współczesnym świecie, społeczne problemy rynku pracy, gerontologia społeczna, starość w ujęciu demograficznym i społecznym, work life balance.
\end{abstract}


wyniki opublikowano na stronie internetowej Głównego Urzędu Statystycznego (https://stat.gov.pl/obszary-tematyczne/zdrowie/zdrowie/stan-zdrowia-ludnosci-polski-w-2014-r-,6,6.html).

Słowa kluczowe: starzenie się społeczeństw, ustugi asystenckie i opiekuńcze, niesamodzielność, osoby starsze

\section{Wstęp}

Starzenie się społeczeństwa jest procesem nieuchronnym i stanowi współcześnie jedno z najważniejszych wyzwań państw rozwiniętych, w tym także Polski. Na skutek spadku umieralności zwłaszcza w populacji osób po 65 roku życia oraz wydłużania się przeciętnego dalszego trwania życia coraz więcej osób dożywa późnej starości, a sam okres starości trwa coraz dłużej. Dodatkowo utrzymujące się od kilku dekad na niskim poziomie współczynniki płodności intensyfikują przebieg tego procesu. Jedną z konsekwencji wzrastającego odsetka osób starszych $^{1}$ jest konieczność zapewnienia opieki niesamodzielnym osobom starszym. Oczywiście nie każda osoba starsza wymaga wsparcia w codziennym funkcjonowaniu, jednakże wraz z postępującym procesem starzenia się społeczeństwa wzrasta zapotrzebowanie na usługi asystenckie i opiekuńcze ${ }^{2}$. Ponadto ryzyko niesamodzielności istotnie wzrasta wraz z przekroczeniem 80 roku życia. Mowa

1 Najczęściej za granicę starości uznaje się osiągnięcie wieku emerytalnego (60 lat dla kobiet i 65 lat dla mężczyzn). Definicje medyczne również uznają za granicę wieku starszego 65 rok życia. Jest to zbieżne z klasyfikacją opracowaną przez Światową Organizację Zdrowia (WHO), która wyróżniła trzy grupy w ramach wieku starszego: 65-75 lat, 75-90 lat oraz 90 lat i więcej.

Zob. M. Luty-Michalak, Przyszłość Polityki ludnościowej w kontekście starzenia się społeczeństwa polskiego, w: Politologia jako nauka? Analiza politologiczna wobec kwestii wspótczesnego świata, red. M. Krzysztofik, D. Gauza Wydawnictwo MAJUS s.c., Zielona Góra 2009, s. 172.

M. Luty-Michalak, Więź międzypokoleniowa w starzejącym się społeczeństwie polskim. Czy jesteśmy świadkami prefiguratywności kulturowego przekazu międzypokoleniowego?, w: Jedność i różnorodność. Kultura vs. kultury, red. E. Rekłajtis, R. Wiśniewski, J. Zdanowski, Oficyna Wydawnicza ASPRA-JR, Warszawa 2010, s. 421.

2 Z. Szweda-Lewandowska, Rynek usług opiekuńczych-perspektywy rozwoju w kontekście starzenia się populacji, „Optimum. Studia Ekonomiczne” 2014, nr 2 (68), s. 148. 
tutaj zarazem o niesamodzielności ekonomicznej, jak również niesamodzielności funkcjonalnej, która bardzo często charakteryzuje właśnie sędziwych starców3.

Niesamodzielność osób starszych nie zawsze jest wynikiem ich niepełnosprawności. Pomocy i opieki bardzo często wymagają osoby u których proces starzenia się przebiega fizjologicznie, a utrata sprawności fizycznej i zdolności do samodzielnego funkcjonowania w środowisku jest właśnie wynikiem fizjologicznego starzenia się organizmu ${ }^{4}$. W związku z tym wraz ze wzrostem liczby oraz odsetka osób starszych w społeczeństwie wzrasta zapotrzebowanie na usługi asystenckie oraz opiekuńcze. Niestety ze względu na uwarunkowania demograficzne sprawowanie opieki nad osobami starszymi przez członków najbliższej rodziny będzie w przyszłości coraz częściej napotykało na trudności. Sytuacja ta determinowana będzie wzrastającym odsetkiem osób starszych w społeczeństwie polskim oraz zmniejszającą się liczbą osób stanowiących potencjalnych opiekunów.

\section{Uwarunkowania demograficzne}

W analizie procesu starzenia się społeczeństw wykorzystywanych jest wiele miar, takich jak chociażby wskaźnik starości, indeks starości, współczynniki obciążenia demograficznego czy też wskaźnik wieku sędziwego. Z punktu widzenia problematyki niniejszego artykułu największe znaczenie ma przedstawienie zmian mediany wieku ludności oraz przeciętnego dalszego trwania życia. Istotna jest także analiza wskaźników opisujących procentowy udział ludności w wieku poniżej 14 lat, od 15 do 64 lat oraz w wieku 65 lat i więcej w populacji ogółem.

Mediana wieku ludności dzieli populację na dwie części. Jest to „taki wiek, którego jedna połowa populacji jeszcze nie osiągnęła, zaś druga już ukończyła"s. Wzrost jej wartości świadczy o postępującym procesie starzenia się społeczeństwa. W Polsce od 1980 roku obserwowany jest stały, systematyczny jej wzrost. $\mathrm{Na}$ początku analizowanego okresu wynosiła ona niespełna 30 lat. W roku 2010 osiągnęła już poziom 38 lat. Wzrost ten obserwowany będzie do roku 2050, gdy osiągnie ona wartość prawie 50 lat. W latach 2050-2080 z niewielkimi zmianami będzie utrzymywała się na stałym poziomie. Oznacza to, że w okresie 100 lat od roku 1980 do roku 2080 wzrośnie ona o 20 lat, a połowa społeczeństwa będzie miała 50 lat i więcej.

\footnotetext{
3 P. Szukalski, Najstarsi Polacy, „Demografia i Gerontologia Społeczna. Biuletyn Informacyjny" 2015, nr 1, s. 1.

4 Z. Szweda-Lewandowska, Rynek..., dz. cyt., s. 149.

5 GUS, Prognoza ludności na lata 2014-2050, Zakład Wydawnictw Statystycznych, Warszawa 2014, s. 127.
} 


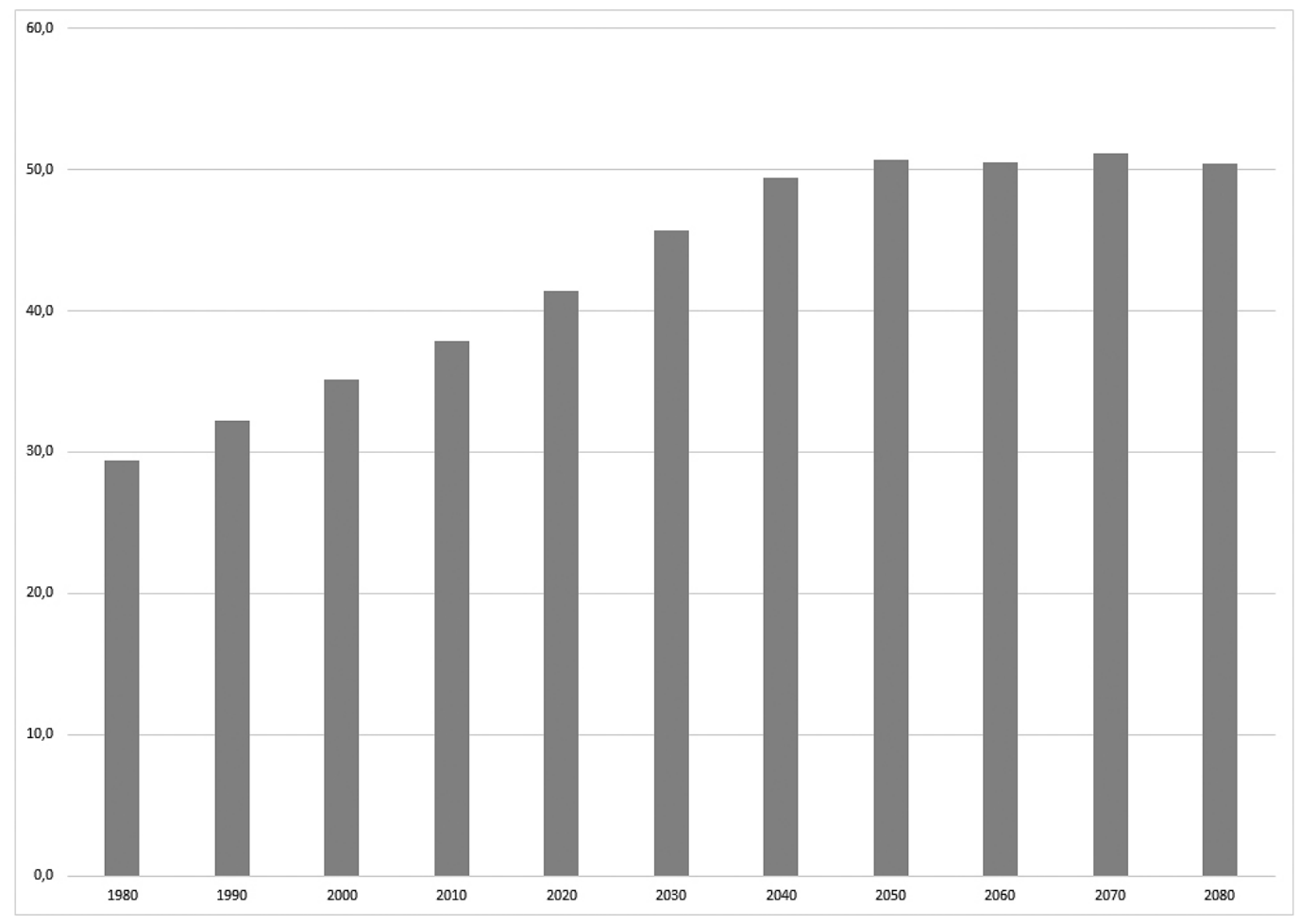

Wykres 1. Mediana wieku w Polsce w latach 1980-2080 (w latach)

Źródło: Eurostat database: population (demo_pop) oraz population projections (proj) (dostęp: 18.10.2018 r.).

Zgodnie z przewidywaniami projekcji Eurostatu w analizowanym okresie nastąpi również zmiana struktury ludności Polski według wieku. Najliczniejszą grupę stanowiły i nadal stanowić będą osoby w wieku produkcyjnym czyli od 15 do 64 roku życia. Jednak ich udział w populacji ogółem zmniejszy się o ponad 12 punktów procentowych z niespełna $67 \% \mathrm{w}$ roku 1980 do 53,5\% w 2080 roku. Biorąc pod uwagę fakt, że członkowie rodziny, którzy sprawują opiekę nad osobami starszymi należą właśnie do tej grupy należy uznać, że będziemy mieli do czynienia z pogłębianiem się niekorzystnych tendencji demograficznych. Ponadto w przyjętej perspektywie czasowej znacznie zmniejszy się liczba dzieci poniżej 15 roku życia, o czym świadczy wartość odsetka osób w wieku 0-14 lat, który w roku 1980 wynosił nieco ponad $24 \%$, natomiast $\mathrm{w}$ roku 2080 spadnie do poziomu niespełna $14 \%$. Z kolei w przypadku odsetka osób starszych (65 lat i więcej) odnotowany zostanie znaczny wzrost jego wartości z poziomu 10\% (1980 rok) do 33\% (2080 rok). Należy podkreślić, że w roku 2017 liczba dziadków przewyższyła liczbę dzieci. W roku 2080 udział osób starszych w populacji będzie wyższy od udziału dzieci o ponad 19 punktów procentowych. Tendencja ta jest niezwykle niepokojąca i wskazuje na znaczne zaawansowanie procesu starzenia się społeczeństwa polskiego. 


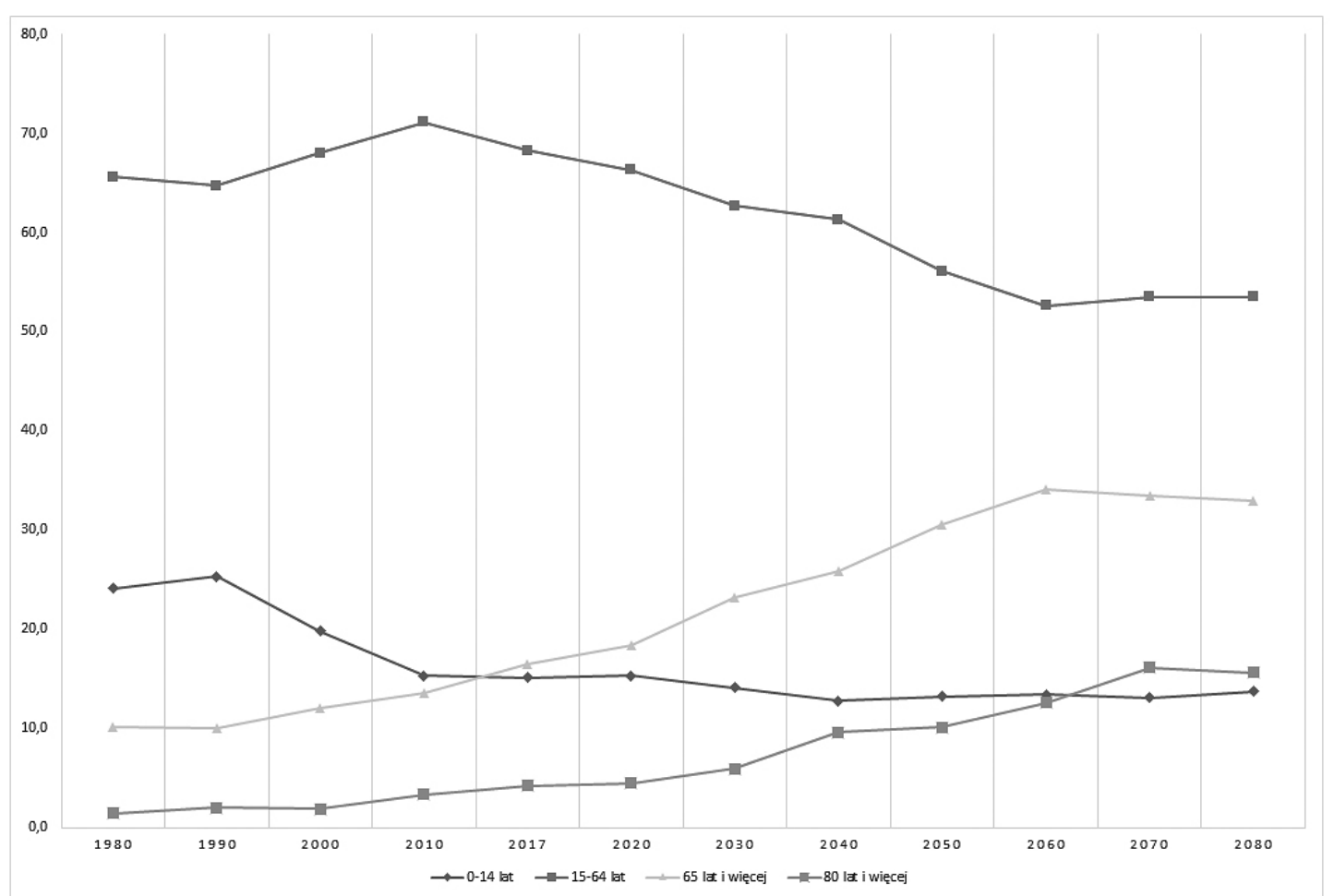

Wykres 2. Struktura ludności Polski według grup wieku w latach 1980-2080 (w procentach)

Źródło: Eurostat database: population (demo_pop) oraz population projections (proj) (dostęp: 18.10.2018 r.).

Niepokój budzi również fakt stałego wzrostu odsetka osób najstarszych (powyżej 80 roku życia). Co więcej, w najbliższych dekadach będzie się on charakteryzował najszybszym tempem wzrostu wskutek ,tzw. podwójnego starzenia się ludności, według którego w społeczeństwach charakteryzujących się niską umieralnością wraz ze wzrostem odsetka osób starszych następuje jednocześnie zmiana struktury tej subpopulacji, polegająca na jeszcze szybszym wzroście liczby osób najstarszych. Generalnie, z im starszą grupą mamy do czynienia, tym wyższe

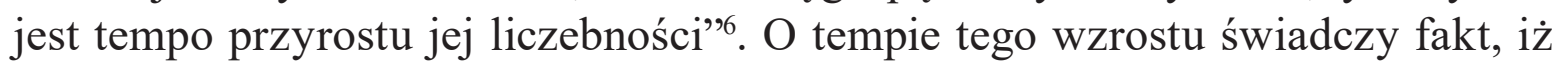
osoby najstarsze w roku 1980 stanowiły niespełna $1,5 \%$ populacji, natomiast $\mathrm{w}$ roku 2080 ich udział będzie wynosił aż 15,6\%. Ponadto w roku 2070 osoby w wieku 80 lat i więcej będą stanowiły liczniejszą część społeczeństwa polskiego niż osoby najmłodsze czyli w wieku 0-14 lat. Należy również podkreślić, że obecnie ponad $2 / 3$ osób sędziwych (w wieku 80 lat i więcej) to osoby owdowiałe, a $85 \%$ z nich stanowią kobiety. Sędziwi starcy w przeważającej części są osobami mieszkającymi i żyjącymi samotnie, które wymagają wsparcia. W związku z tym tak dynamiczny

6 P. Szukalski, Ludzie bardzo starzy - niewidoczna grupa docelowa polityki społecznej?, „Studia Demograficzne” 2014, nr 2(166), s. 59. 


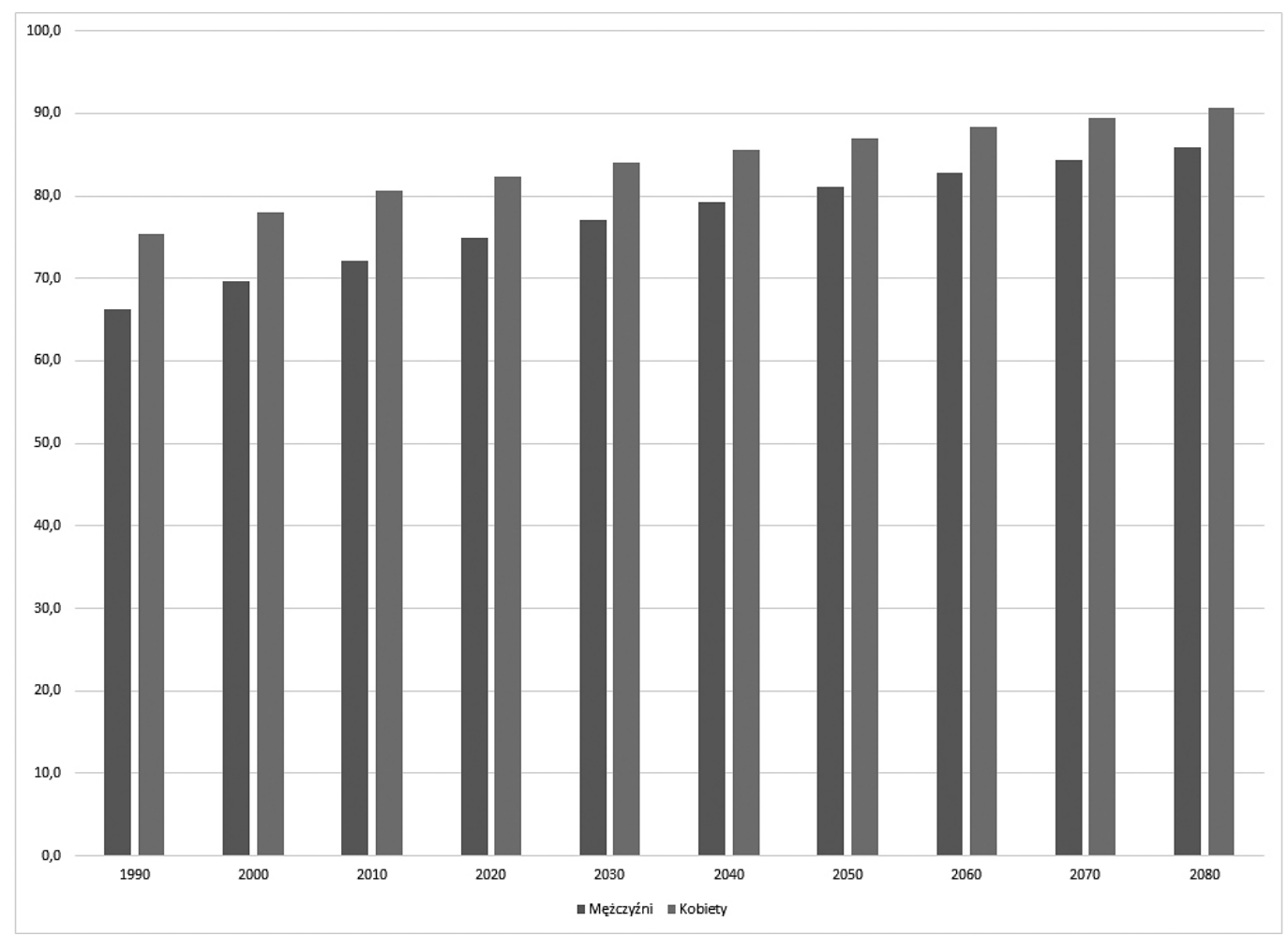

Wykres 3. Przeciętne trwanie życia w Polsce w latach 1990-2080 (w latach)

Źródło: Eurostat database: mortality (demo_mor) oraz population projections (proj) (dostęp: 18.10.2018 r.).

wzrost odsetka tej części populacji oznacza w przyszłości narastanie problemu samodzielnej egzystencji tych osób, które wymagać będą pomocy oraz opieki ${ }^{7}$.

Wskutek szybkiego rozwoju medycyny, a także zmiany stylu życia Polaków wydłużeniu ulega również trwanie ich życia. Lata 90. XX wieku zapoczątkowały okres stałego wzrostu przeciętnego trwania życia w Polsce. Spadek natężenia zgonów spowodował, że przeciętne trwanie życia noworodka płci męskiej wzrosło z 66,3 lat w roku 1980 do 72,2 lat w roku 2010. Kobiety żyją dłużej niż mężczyźni, ponieważ w 1980 roku przeciętne trwanie ich życia wynosiło 75,3 lat, w roku 2010 - 80,7 lat. Warto jednak podkreślić, że różnica w wartości tego parametru pomiędzy kobietami, a mężczyznami zmniejsza się. W roku 1980 wynosiła ona bowiem 9 lat, natomiast $\mathrm{w}$ roku 2080 wyniesie niespełna 5 lat. W końcowym roku analizowanego okresu noworodek płci męskiej będzie miał szansę dożyć 85,9

7 GUS, Notatka przygotowana na posiedzenie Sejmowej Komisji Polityki Senioralnej dotyczace ,Informacji Ministra Zdrowia na temat wptywu zmian demograficznych i starzenia się spoleczeństwa na organizację systemu ochrony zdrowia i Narodowy Program Zdrowia" (w dniu 19.02.2016 r.), s. 11 www.stat.gov.pl (dostęp 19.10.2018 r.). 


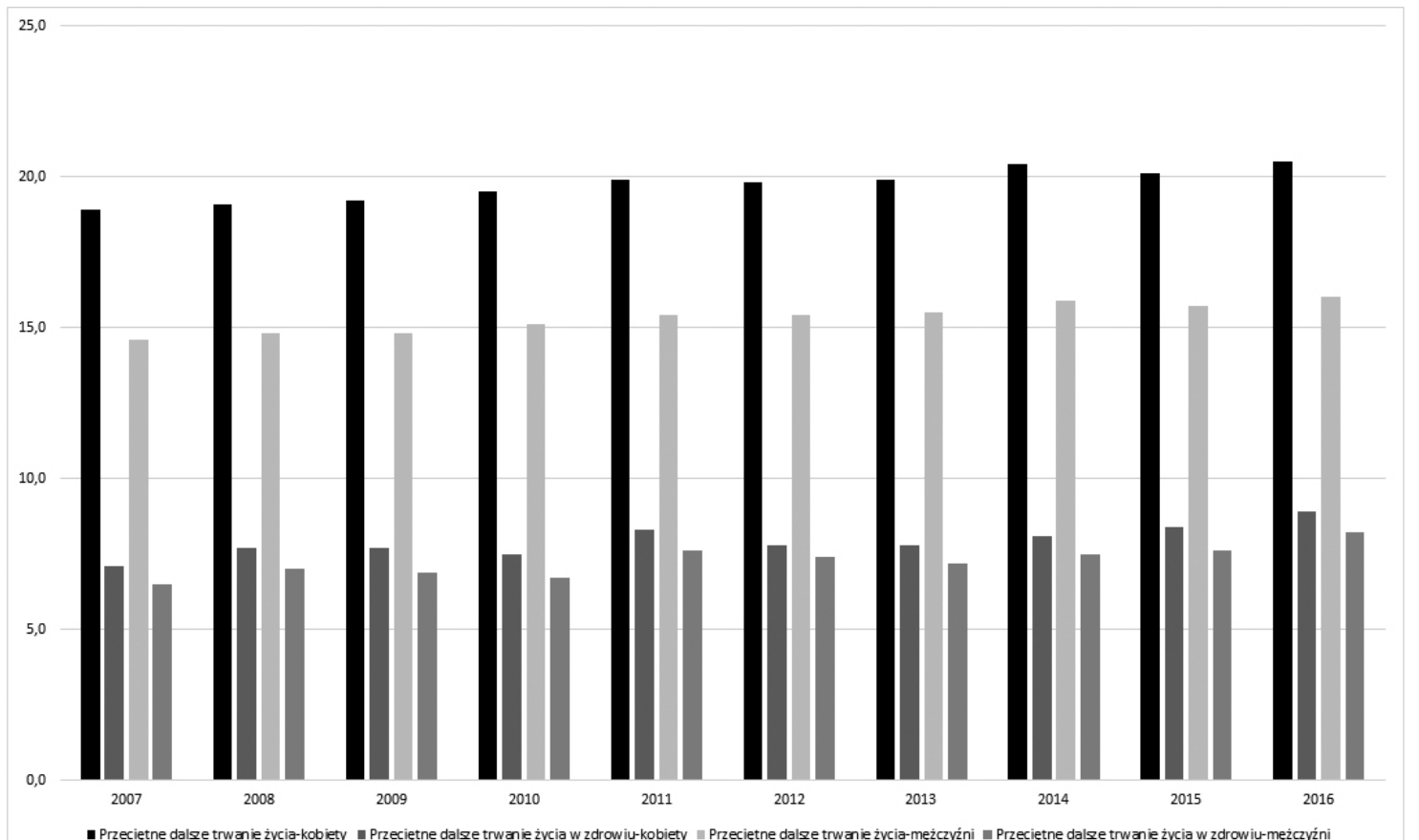

Wykres 4. Przeciętne dalsze trwanie życia oraz przeciętne dalsze trwanie życia w zdrowiu kobiet i mężczyzn w wieku 65 lat w Polsce w latach 2007-2016 (w latach)

lat, natomiast noworodek płci żeńskiej 90,6 lat. W przypadku mężczyzn średnia długość życia wydłuży się aż o niespełna 20 lat, natomiast w przypadku kobiet jedynie o nieco ponad 15 lat.

Pełniejszy obraz sytuacji demograficznej można uzyskać porównując dane dotyczące przeciętnego dalszego trwania życia ze stanem zdrowia ludności, którego znakomitą ilustrację empiryczną stanowi przeciętne dalsze trwanie życia w zdrowiu. „Wskaźnik przeciętnego trwania życia w zdrowiu określa dla osoby (o danej płci i wieku) średnią liczbę lat życia bez niepełnosprawności (w zdrowiu). Zatem, wskaźnik ten dodaje wymiar jakościowy do przewidywanej liczby lat życia i pozwala na obserwację, czy dłuższe życie oznacza jednocześnie dłuższe życie w dobrym zdrowiu"s.

Na wykresie 4 przedstawiono przedmiotowe informacje dla kobiet i mężczyzn w wieku 65 lat. Przeciętne dalsze trwanie życia Polek w wieku 65 lat w całym analizowanym okresie było dłuższe niż dalsze trwanie życia Polaków w tym samym wieku. W 2016 roku wynosiło ono odpowiednio 20,5 roku oraz 16 lat i wydłużyło się w ciągu ostatniej dekady zarówno w przypadku kobiet (o 1,6 roku), jak również i mężczyzn (o 1,4 roku). Na podkreślenie zasługuje fakt, że przeciętne dalsze

8 GUS, Notatka ..., dz. cyt., s. 7. 
trwanie życia w zdrowiu uległo nieznacznie większemu wydłużeniu. Kobiety w wieku 65 lat średnio miały szansę żyć w zdrowiu w 2007 roku kolejne 7,1 lat, natomiast $\mathrm{w}$ roku 2016 - 8,9 lat (wzrost o 1,8 lat). W przypadku mężczyzn odpowiednie wartości wynosiły 6,5 lat oraz 8,2 lat (wzrost o 1,7 lat). Niepokojące jest jednak zjawisko tak dużych dysproporcji pomiędzy przeciętnym dalszym trwaniem życia oraz przeciętnym dalszym trwaniem życia w zdrowiu. Otóż dalsze trwanie życia w zdrowiu w Polsce dla kobiet w wieku 65 lat stanowiło w 2007 roku jedynie niespełna 38\% dalszego trwania życia, natomiast dla mężczyzn 44,5\%. W 2016 roku sytuacja wyglądała bardziej optymistycznie, ponieważ udział procentowy pozostałego życia w zdrowiu zwiększył się i wynosił w przypadku kobiet 43,5\%, a w przypadku mężczyzn nieco ponad 52\%. Wyraźnie więc widać, że mimo iż dalsze trwanie życia mężczyzn w wieku 65 lat jest krótsze niż kobiet, to większa jego część przeżywana jest przez nich w zdrowiu.

\section{Ryzyko niesamodzielności wśród osób starszych}

Wraz z wiekiem wzrasta prawdopodobieństwo niesamodzielności, która definiowana jest najczęściej jako „niemożność samodzielnego wykonywania czynności dnia codziennego i konieczność korzystania z pomocy osób trzecich przy zaspokajaniu tychże potrzeb". . Do pomiaru stopnia niesamodzielności wykorzystywane są różnorodne skale. W celu oceny samodzielności w zakresie wykonywania podstawowych czynności życia codziennego takich jak: mycie, ubieranie się, jedzenie, poruszanie się, kontrolowanie czynności fizjologicznych czy korzystanie z toalety wykorzystuje się najczęściej skalę Activities of Daily Living w skrócie ADL. Natomiast do oceny poziomu samodzielności przy wykonywaniu złożonych czynności życia codziennego, do których zalicza się między innymi korzystanie z telefonu, korzystanie z komunikacji publicznej, zakupy, przygotowywanie posiłków, prace domowe, przyjmowanie leków oraz gospodarowanie pieniędzmi służy skala Instrumental Activities of Daily Living w skrócie IADL ${ }^{10}$. Niestety

9 Z. Szweda-Lewandowska, Modele opieki nad osobami niesamodzielnymi, „Studia Ekonomiczne. Zeszyty Naukowe Uniwersytetu Ekonomicznego w Katowicach" 2014, nr 179, s. 215.

10 B. Winzer, A. Skalska, A. Klich-Rączka, K. Piotrowicz, T. Grodzicki, Ocena stanu funkcjonalnego u osób w starszym wieku, w: Aspekty medyczne, psychologiczne, socjologiczne i ekonomiczne starzenia się ludzi w Polsce, red. M. Mossakowska, A. Więcek, P. Błędowski, Termedia Wydawnictwa Medyczne, Poznań 2012, s. 82-83. 


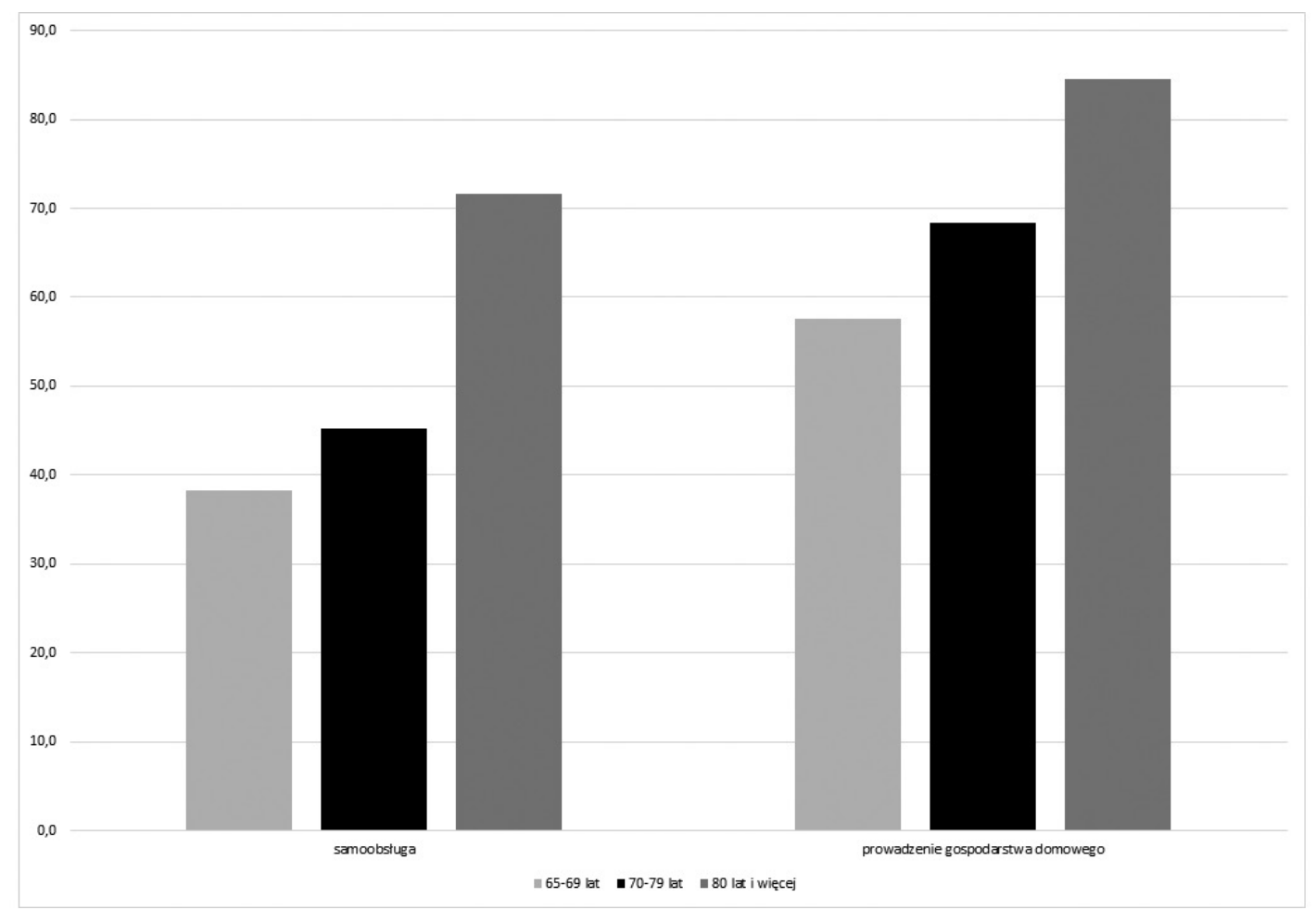

Wykres 5. Korzystanie z pomocy innej osoby lub urządzeń w zakresie samoobsługi oraz prowadzenia gospodarstwa domowego (w procentach)

Źródło: GUS: Stan zdrowia ludności Polski w 2014 r. - tablice, https://stat.gov.pl/obszary-tematyczne/zdrowie/zdrowie/stan-zdrowia-ludnosci-polski-w-2014-r-,6,6.html (dostęp: 18.10.2018 r.).

w Polsce nie przeprowadzono jak dotąd badań z wykorzystaniem powyższych skal dla całej populacji ${ }^{11}$.

Badania potrzeb opiekuńczych, jak również poziomu niesamodzielności osób starszych opierają się na dwóch rodzajach wskaźników: obiektywnych oraz subiektywnych. Wskaźniki o charakterze subiektywnym budowane są najczęściej na podstawie deklaracji respondentów odnośnie korzystania z pomocy innych osób lub urządzeń przy wykonywaniu czynności życia codziennego. Z kolei wskaźniki obiektywne określają stopień niesamodzielności osób badanych na podstawie empirycznych wskaźników sprawności ${ }^{12}$. W tej części artykułu zaprezentowane zostaną dane w oparciu o wymienione wyżej typy wskaźników. Poniższe informacje zaczerpnięto z reprezentatywnego Europejskiego Ankietowego Badania Zdrowia (European Health Interview Survey - EHIS), które przeprowadzane jest

11 Z. Szweda-Lewandowska, Modele..., dz. cyt., s. 216.

12 P. Błędowski, B. Szatur-Jaworska, Z. Szweda-Lewandowska, P. Kubicki, Raport na temat sytuacji osób starszych w Polsce, IPiSS, Warszawa 2012, s. 57. 


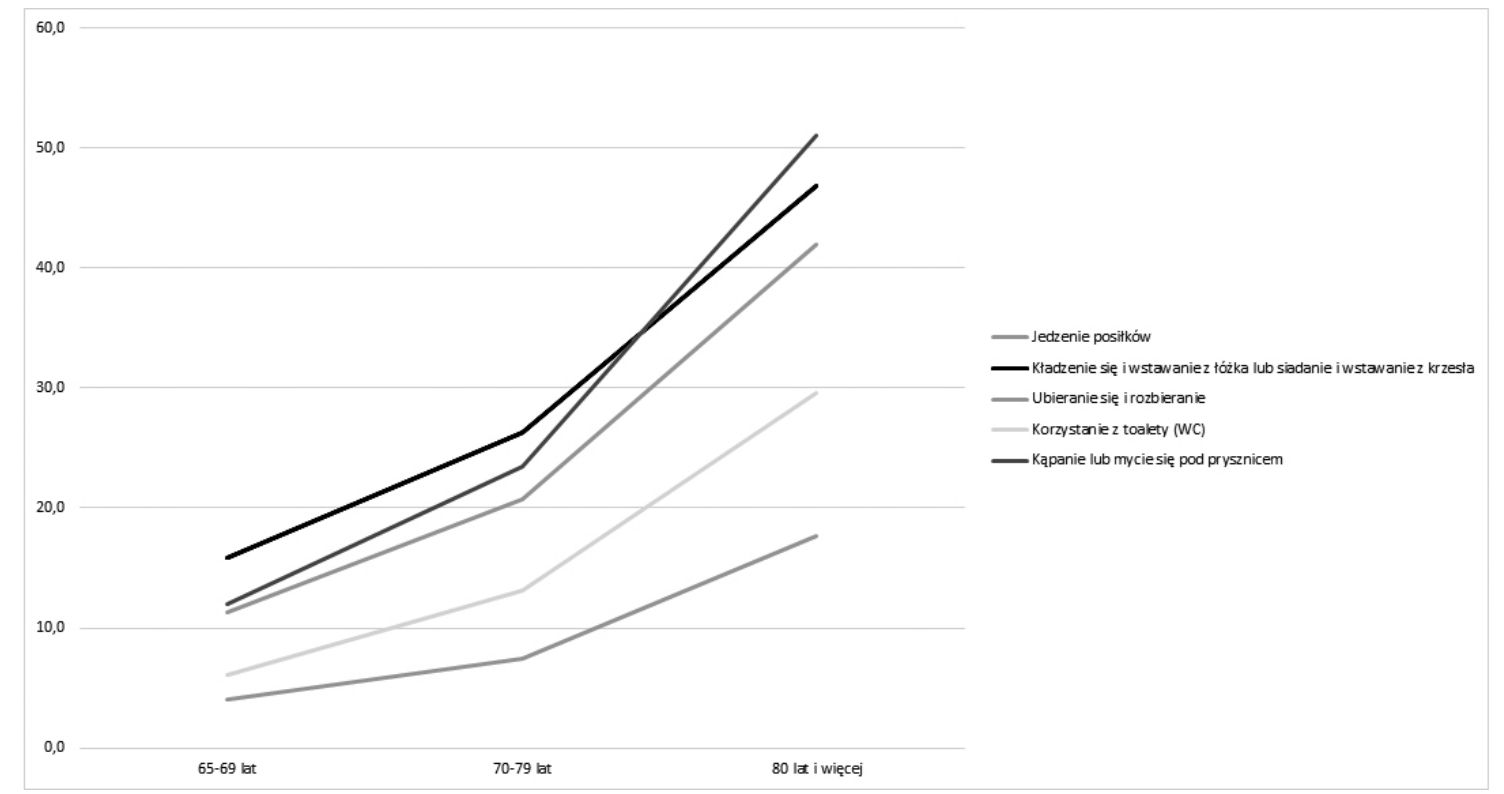

Wykres 6. Trudności w samoobsłudze (w \%)

Źródło: GUS, Stan zdrowia ludności Polski w 2014 r. - tablice, https://stat.gov.pl/obszary-tematyczne/zdrowie/zdrowie/stan-zdrowia-ludnosci-polski-w-2014-r-,6,6.html (dostęp: 18.10.2018 r.).

cyklicznie co 5 lat, a ostatnie odbyło się w 2014 roku. Udział w tej części badania wzięły osoby w wieku 65 lat i więcej, które nie zamieszkiwały w placówkach opiekuńczych ${ }^{13}$.

Jedną z poruszanych kwestii w trakcie ostatniego badania była zdolność do samoobsługi oraz do samodzielnego prowadzenia gospodarstwa domowego. W obydwu przypadkach konieczność korzystania z pomocy innych osób lub urządzeń wzrastała wraz z wiekiem. Nieco ponad 38\% osób w wieku 65-69 lat, 45,3\% osób w wieku 70-79 lat i ponad 71,5\% seniorów w wieku 80 lat i więcej zmuszonych było do korzystania z takiej pomocy przy wykonywaniu czynności życia codziennego takich jak: spożywanie posiłków, kładzenie się lub wstawanie, ubieranie się i rozbieranie, korzystanie z toalety czy też kąpanie się. W przypadku prowadzenia gospodarstwa domowego odsetki te były wyższe i wynosiły odpowiednio: 57,6\%; $68,4 \%$ oraz $84,6 \%$.

Osobom w wieku 65-69 lat najwięcej trudności sprawiało kładzenie się i wstawanie z łóżka lub siadanie i wstawanie z krzesła (15,9\%), kąpanie lub mycie się pod prysznicem (12\%) oraz ubieranie się i rozbieranie $(11,3 \%)$. Nieco ponad $6 \%$ osób w tym wieku wskazało, że ma problemy z samodzielnym korzystaniem z toalety,

13 Zob. GUS, Stan zdrowia ludności Polski w 2014 r., Zakład Wydawnictw Statystycznych, Warszawa 2016. 


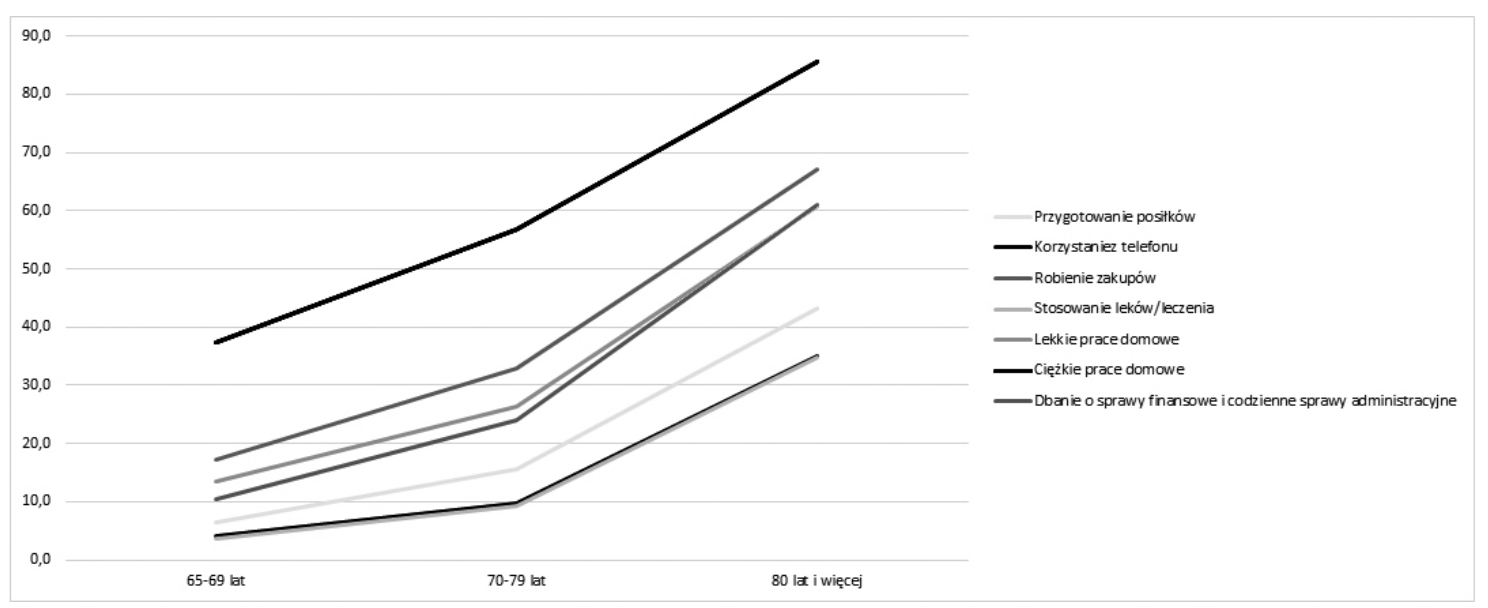

Wykres 7. Trudności w prowadzeniu gospodarstwa domowego (w \%)

Źródło: GUS, Stan zdrowia ludności Polski w 2014 r. - tablice, https://stat.gov.pl/obszary-tematyczne/zdrowie/zdrowie/stan-zdrowia-ludnosci-polski-w-2014-r-,6,6.html (dostęp: 18.10.2018 r.).

a jedynie $4 \%$ z jedzeniem posiłków. W przypadku wymienionych czynności samoobsługowych trudność z ich wykonywaniem wzrasta i to znacząco wraz z wiekiem, zwłaszcza po przekroczeniu granicy tzw. czwartego wieku czyli 80 lat. Osoby w tym wieku najczęściej miały problemy z kąpaniem się (51\%), kładzeniem się lub siadaniem oraz wstawaniem (46,8\%), ubieraniem się i rozbieraniem $(42 \%)$, jak również korzystaniem z toalety (26\%). Najrzadziej wskazywano jedzenie posiłków (17,7\%). Uogólniając należy stwierdzić, że w grupie wiekowej 65-69 lat co piąta osoba deklarowała problemy z wykonaniem codziennych czynności związanych z samoobsługą (19,7\%), wśród osób w wieku 70-79 lat była to co trzecia osoba (31,7\%), a wśród osób najstarszych była to już co druga osoba (58\%).

Znacznie większe trudności sprawia seniorom prowadzenie gospodarstwa domowego. Ciężkie prace domowe stanowią problem dla 37,4\% osób w wieku 65-69 lat, niespełna 57\% osób w wieku 70-79 lat i prawie 86\% sędziwych starców. Na drugim miejscu wskazywano trudności z robieniem zakupów (65-69 lat $-37,4 \% ; 70-79$ lat $-56,8 \%$; 80 lat i więcej - 85,6\%), a na trzecim lekkie prace domowe (odpowiednio: $13,4 \% ; 26,3 \%$ oraz $60,8 \%$ ). Dbanie o sprawy finansowe i codzienne sprawy administracyjne sprawia kłopot co dziesiątej osobie w wieku 65-69 lat, co piątej w wieku 70-79 lat i niespełna 60\% najstarszych osób. Z kolei trudności z przygotowywaniem posiłków deklaruje co druga osoba starsza (w tym w wieku 65-69 lat - 6,5\%; 70-79 lat-15,6\%; 80 lat i więcej - 43,3\%). Na ostatnim miejscu znalazło się korzystanie z telefonu (65-69 lat - 4\%; 70-79 lat $-9,7 \% ; 80$ lat i więcej - 35,1\%). 
Powyższa analiza wskazuje na ogromne zapotrzebowanie na pomoc wśród seniorów zarówno przy czynnościach samoobsługowych, jak i przy prowadzeniu gospodarstwa domowego. Niestety $45 \%$ seniorów mających problemy z samoobsługą musiało radzić sobie samodzielnie, ponieważ nie otrzymywali oni żadnego wsparcia, a $40 \%$ populacji osób w wieku 65 lat i więcej zadeklarowało potrzebę korzystania z pomocy innej osoby lub urządzeń przy wykonywaniu czynności samoobsługowych (65-69 lat - 25\%; 70-79 lat-37,1\%; 80 lat i więcej - 52,1\%). Co trzecia osoba starsza mająca trudności z prowadzeniem gospodarstwa domowego odpowiedziała, że niestety nie korzysta z pomocy innych osób lub urządzeń, a prawie co druga osoba chciałby z takiej pomocy skorzystać (65-69 lat - 30,9\%; 70-79 lat - 39,3\%; 80 lat i więcej-53,2\%).

\section{Możliwości opiekuńcze rodziny}

Dokonana analiza wskazuje na niekorzystną zmianę relacji pomiędzy głównymi grupami wieku ludności: 0-14 lat, 15-64 lata oraz 65 lat i więcej oraz na niezaspokojenie potrzeb opiekuńczych znacznej części osób starszych. Na jej podstawie można wysnuć wniosek, że potencjał opiekuńczy rodziny już współcześnie jest ograniczony, a w przyszłości tendencja ta będzie ulegała pogłębieniu. Aby uzasadnić to stwierdzenie w tabeli 1 zaprezentowane zostały wyniki analizy trzech współczynników: potencjalnego wsparcia, wsparcia rodziców i potencjału pielęgnacyjnego. Współczynnik potencjalnego wsparcia mówi o tym, ile osób w wieku 15-64 lata przypada na 100 osób w wieku 65 lat i więcej. Współczynnik wsparcia rodziców określa stosunek osób w wieku 85 lat i więcej do osób w wieku 50-64 lata. Natomiast współczynnik potencjału pielęgnacyjnego jest stosunkiem wyrażającym liczbę kobiet w wieku 45-64 lat przypadającą na 100 osób w wieku 80 lat i więcej. Określa on więc wielkość potencjału pielęgnacyjnego kobiet w badanej populacji, ponieważ to właśnie najczęściej kobiety są opiekunkami niesamodzielnych osób starszych ${ }^{14}$.

Wartości wszystkich współczynników wskazują na niekorzystną sytuację pod koniec analizowanego okresu. Współczynnik potencjalnego wsparcia wynosił w 1980 roku 644, natomiast w roku 2080 wyniesie nieco ponad 162 co oznacza, że liczba osób w wieku produkcyjnym przypadająca na 100 osób w wieku poprodukcyjnym spadnie prawie czterokrotnie. Natomiast liczba osób w wieku 85 lat i więcej przypadająca na 100 osób w wieku 50-64 lata wzrośnie z 3 w roku 1980 do prawie 60 w roku 2080. Jednocześnie liczba kobiet w wieku 45-64 lata, która przypada na 100

14 M. Luty-Michalak, „Sandwich generation” - pokolenie kobiet podwójnie obciażonych obowiązkami opiekuńczymi, w: Obraz współczesnej rodziny. Teoria i badania, red. B. Szluz, Wydawnictwo Uniwersytetu Rzeszowskiego, Rzeszów 2017, s. 218. 
osób w wieku 80 lat i więcej spadnie z 767 w roku 1980 do niespełna 72 w roku 2080, co wskazuje na fakt, że liczba sędziwych starców przekroczy liczbę potencjalnych opiekunek, a co za tym idzie możliwości opiekuńcze rodziny zostaną w znacznym stopniu ograniczone i w przypadku wielu osób starszych okażą się niewystarczające.

Tabela 1. Współczynniki: potencjalnego wsparcia, wsparcia rodziców i potencjału pielęgnacyjnego w Polsce w latach 1980-2080

\begin{tabular}{|l|c|c|c|}
\hline Rok & $\begin{array}{c}\text { Wspólczynnik poten- } \\
\text { cjalnego wsparcia }\end{array}$ & $\begin{array}{c}\text { Wspólczynnik wsparcia } \\
\text { rodziców }\end{array}$ & $\begin{array}{c}\text { Współczynnik potencjału } \\
\text { pielęgnacyjnego }\end{array}$ \\
\hline $\mathbf{1 9 8 0}$ & 644,08 & 3,34 & 767,90 \\
\hline $\mathbf{1 9 9 0}$ & 650,87 & 4,53 & 531,69 \\
\hline $\mathbf{2 0 0 0}$ & 560,66 & 6,29 & 616,10 \\
\hline $\mathbf{2 0 1 0}$ & 524,12 & 6,02 & 431,53 \\
\hline $\mathbf{2 0 2 0}$ & 359,98 & 11,17 & 298,09 \\
\hline $\mathbf{2 0 3 0}$ & 270,09 & 12,84 & 241,12 \\
\hline $\mathbf{2 0 4 0}$ & 237,14 & 20,70 & 156,29 \\
\hline $\mathbf{2 0 5 0}$ & 183,29 & 29,91 & 122,84 \\
\hline $\mathbf{2 0 6 0}$ & 154,38 & 40,45 & 87,26 \\
\hline $\mathbf{2 0 7 0}$ & 160,18 & 54,24 & 72,24 \\
\hline $\mathbf{2 0 8 0}$ & 162,62 & 59,99 & 71,71 \\
\hline
\end{tabular}

Źródło: obliczenia własne na podstawie: Eurostat database: population (demo_pop) oraz population projections (proj) (dostęp: 18.10.2018 r.).

\section{Podsumowanie}

W ciągu kilku najbliższych dekad, Polska, która po II wojnie światowej była jednym z najmłodszych społeczeństw europejskich dołączy do grona najstarszych państw naszego kontynentu. Dokonana w tym artykule analiza demograficzna jednoznacznie wskazuje, że proces ten jest nieuchronny, a jego przebieg będzie, w porównaniu z innymi społeczeństwami europejskimi, gwałtowny. Ponadto w perspektywie do roku 2080 ogólna liczba ludności Polski zmniejszy się o prawie $9 \mathrm{mln}$ i wynosić będzie $29 \mathrm{mln}$ osób. Przy czym spadek ten determinowany będzie zmniejszającą się liczbą dzieci, ponieważ ich udział w populacji ogółem będzie malał, przy jednoczesnym wzroście liczby oraz odsetka osób starszych.

Możliwości opiekuńcze rodziny będą malały, co stanowi ogromne wyzwanie dla polityki senioralnej państwa w zakresie organizacji opieki nad osobami starszymi w Polsce, zwłaszcza, że wyniki Europejskiego Ankietowego Badania Zdrowia wskazują na znaczące zapotrzebowanie na usługi asystenckie i opiekuńcze 
wśród osób starszych. Kwestia ta jest niezwykle istotna, ponieważ w Polsce to nadal kobiety są najczęściej opiekunkami osób starszych, zwłaszcza te w wieku 45-64 lat, a wskaźnik potencjału pielęgnacyjnego wskazuje, że już w roku 2060 potencjalnych opiekunek będzie w naszym kraju mniej niż sędziwych starców, którzy najczęściej wymagają wsparcia w codziennym życiu.

W świetle wniosków płynących z przeprowadzonej analizy, jak również biorąc pod uwagę fakt, że społeczeństwo polskie w większości przejawia tradycyjne poglądy dotyczące sprawowania opieki nad seniorami sprzeciwiając się ich umieszczaniu w domach pomocy społecznej, należy podjąć jak najszybsze działania zmierzające do stworzenia systemu opieki nad niesamodzielnymi osobami starszymi, który oparty byłby na usługach asystenckich i opiekuńczych świadczonych w środowisku domowym seniorów.

\section{Bibliografia}

Błędowski P., Szatur-Jaworska B., Szweda-Lewandowska Z., Kubicki P., Raport na temat sytuacji osób starszych w Polsce, IPiSS, Warszawa 2012.

GUS, Prognoza ludności na lata 2014 - 2050, Zakład Wydawnictw Statystycznych, Warszawa 2014.

GUS, Notatka przygotowana na posiedzenie Sejmowej Komisji Polityki Senioralnej dotyczace ,Informacji Ministra Zdrowia na temat wplywu zmian demograficznych $i$ starzenia się spoleczeństwa na organizacje systemu ochrony zdrowia i Narodowy Program Zdrowia" (w dniu 19.02.2016 r.), www.stat.gov.pl (dostęp 19.10.2018 r.).

GUS, Stan zdrowia ludności Polski w 2014 r., Zakład Wydawnictw Statystycznych, Warszawa 2016.

Luty-Michalak M., Przyszłość Polityki ludnościowej w kontekście starzenia się spoteczeństwa polskiego, w: Politologia jako nauka? Analiza politologiczna wobec kwestii współczesnego świata, red. M. Krzysztofik, D. Gauza, Wydawnictwo MAJUS s.c., Zielona Góra 2009, s. 171-183.

Luty-Michalak M., Więź międzypokoleniowa w starzejącym się społeczeństwie polskim. Czy jesteśmy świadkami prefiguratywności kulturowego przekazu międzypokoleniowego?, w: Jedność i różnorodność. Kultura vs. kultury, red. E. Rekłajtis, R. Wiśniewski, J. Zdanowski, Oficyna Wydawnicza ASPRA-JR, Warszawa 2010, s. 417-430.

Luty-Michalak M., „Sandwich generation” - pokolenie kobiet podwójnie obciażonych obowiązkami opiekuńczymi, w: Obraz wspótczesnej rodziny. Teoria i badania, red. B. Szluz, Wydawnictwo Uniwersytetu Rzeszowskiego, Rzeszów 2017, s. 2111-220. 
Szukalski P., Ludzie bardzo starzy - niewidoczna grupa docelowa polityki spotecznej?, „Studia Demograficzne” 2014, nr 2(166), s. 57-78.

Szukalski P., Najstarsi Polacy, „Demografia i Gerontologia Społeczna. Biuletyn Informacyjny" 2015, nr 1, s. 1-4.

Szweda-Lewandowska Z., Modele opieki nad osobami niesamodzielnymi, „Studia Ekonomiczne. Zeszyty Naukowe Uniwersytetu Ekonomicznego w Katowicach 2014, nr 179, s. 215-224.

Szweda-Lewandowska Z., Rynek ustug opiekuńczych - perspektywy rozwoju w kontekście starzenia się populacji, „Optimum. Studia Ekonomiczne” 2014, nr 2 (68), s. 148-157.

Winzer B., Skalska A., Klich-Rączka A., Piotrowicz K., Grodzicki T., Ocena stanu funkcjonalnego u osób w starszym wieku, w: Aspekty medyczne, psychologiczne, socjologiczne i ekonomiczne starzenia się ludzi w Polsce, red. M. Mossakowska, A. Więcek, P. Błędowski, Termedia Wydawnictwa Medyczne, Poznań 2012, s. 81-94.

\section{Marta Luty-Michalak: Demographic determinants of the demand for assistant and care services among the elderly in Poland}

\section{Summary}

Demand for assistant and care services for the elderly is determined, among other reasons, by demographic determinants. Poland, like other developed countries, is experiencing a progressive population ageing process. In the coming few decades, the dynamics of this process will increase significantly. The ageing of societies implies many challenges, including the necessity to provide care to dependent elderly people. The aim of the article is to analyze selected demographic determinants of the ageing process of Polish society. The subject of the analysis is to verify the hypothesis about decreasing possibilities of taking care of the elderly by members of the family in the light of the progressive ageing process of the Polish society in the time perspective up to 2080. Data used in article come from the Eurostat database (https://ec.europa.eu/eurostat/data/database) and from the research entitled: Health Status of the Polish Population in 2014 carried out by the Central Statistical Office (https://stat.gov.pl/obszary-tematyczne/zdrowie/ zdrowie/stan-zdrowia-ludnosci-polski-w-2014-r-,6,6.html).

Key words: aging of societies, assistant and care services, dependence, older people 